Supplement of The Cryosphere, 10, 1361-1380, 2016

http://www.the-cryosphere.net/10/1361/2016/

doi:10.5194/tc-10-1361-2016-supplement

(C) Author(s) 2016. CC Attribution 3.0 License.

(c) (i)

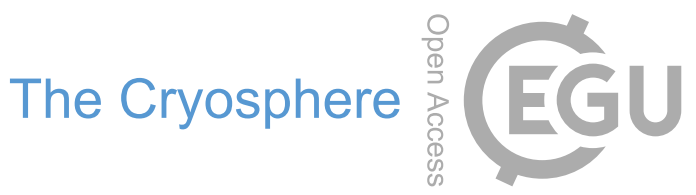

Supplement of

\title{
Mapping snow depth in open alpine terrain from stereo satellite imagery
}

R. Marti et al.

Correspondence to: S. Gascoin (simon.gascoin@cesbio.cnes.fr)

The copyright of individual parts of the supplement might differ from the CC-BY 3.0 licence. 


\section{Contents}

\begin{tabular}{|lll}
\hline 1 & Study site & 1
\end{tabular}

2 Photogrammetric processing $\quad 2$

2.1 ASP's parameters used to generate the DEMs from the Pleiades images. . . . . . . 2

2.2 Raw cloud from the snow-free Pleiades triplet . . . . . . . . . . . . . . . . 3

2.3 Raw cloud from the winter Pleiades triplet . . . . . . . . . . . . . . . . . . . . . . 4

3 Random error assessments 5

\begin{tabular}{|lll}
\hline & Supplementary table & 5
\end{tabular}

\section{Study site}

Fig. 11 shows the land cover map of Bassies catchment.

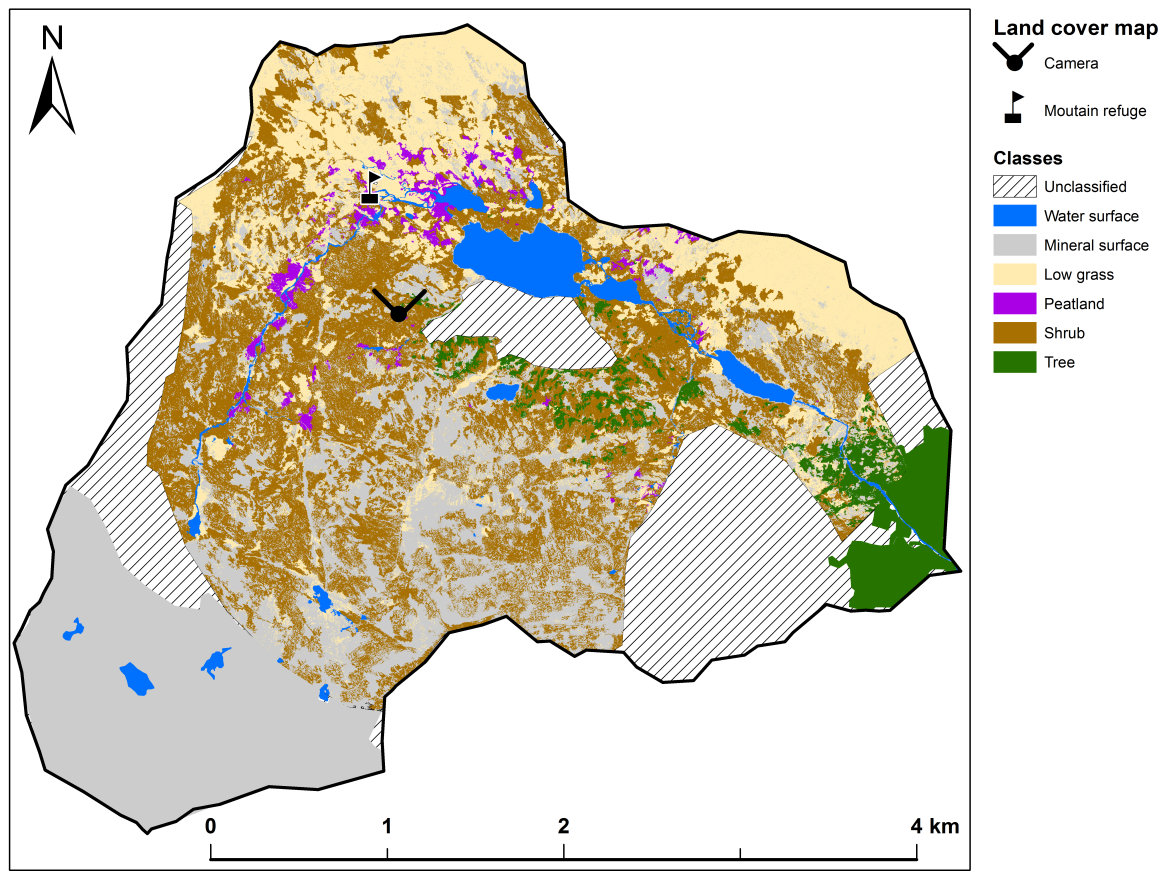

Figure 1: Land cover map of Bassies catchment. 


\section{$2 \quad$ Photogrammetric processing}

\subsection{ASP's parameters used to generate the DEMs from the Pleiades images.}

We present in the following table the parameter set used to treat the flow of data through the Stereo Pipeline.

\begin{tabular}{c|c|c} 
Stage & Parameter set & Selected parameter \\
\hline Registration & ISIS adjust & No bundle adjustment \\
\hline Stereo pre-processing & Pre-alignment options & Affine epipolar \\
& Intensity Normalization & Use entire input range \\
& Preprocessing filter & Laplacian of Gaussian \\
prefilter-kernel-width 1.4 & from disparity map \\
& Correlation Seed Mode & corr-max-levels 3 \\
& Correlation number of pyramids & corr-sub-seed-percent 0.25 \\
\hline Disparity map initialization & Correlation sub seed value & normalized cross correlation \\
& cost function & corr-kernel 25 25 \\
& correlation kernel size & corr-search -80 -2 20 2 \\
& correlation window size & affine window 600 \\
\hline Sub-pixel refienement & Correlation time out & kernel 35 35 \\
\hline Subpixel modes & disable-fill-holes \\
& correlation kernel size & filter mode 1 \\
\hline Outlier rejection / Hole filling & Fill in holes with an inpainting method & rm-half-kernel 5 5 \\
& Automatic "erode" low confidence pixels & max-mean-diff 3 \\
& & rm-min-matches 60 \\
& & rm-threshold 3 \\
\hline Stereo triangulation & & 0.0 \\
& & 0.0 \\
\hline
\end{tabular}




\subsection{Raw cloud from the snow-free Pleiades triplet}

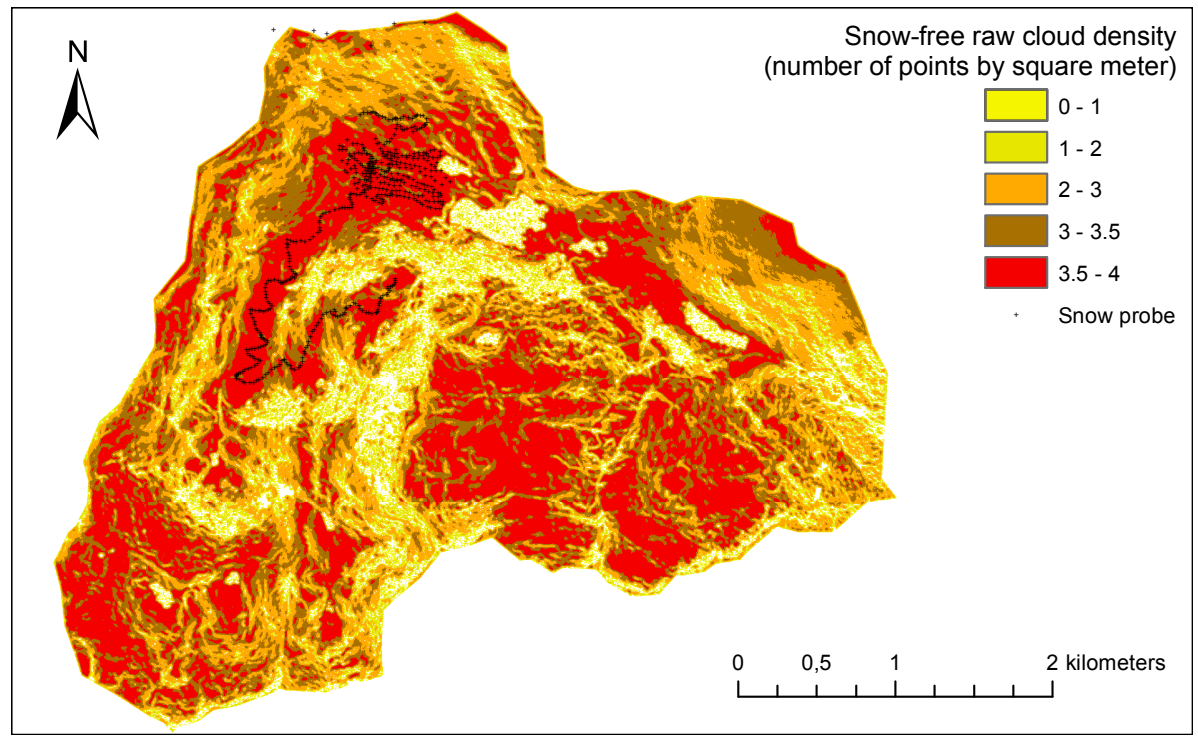

Figure 2: Density of the point cloud generated from the snow-free Pleiades triplet image (number of points per square meter). 


\subsection{Raw cloud from the winter Pleiades triplet}

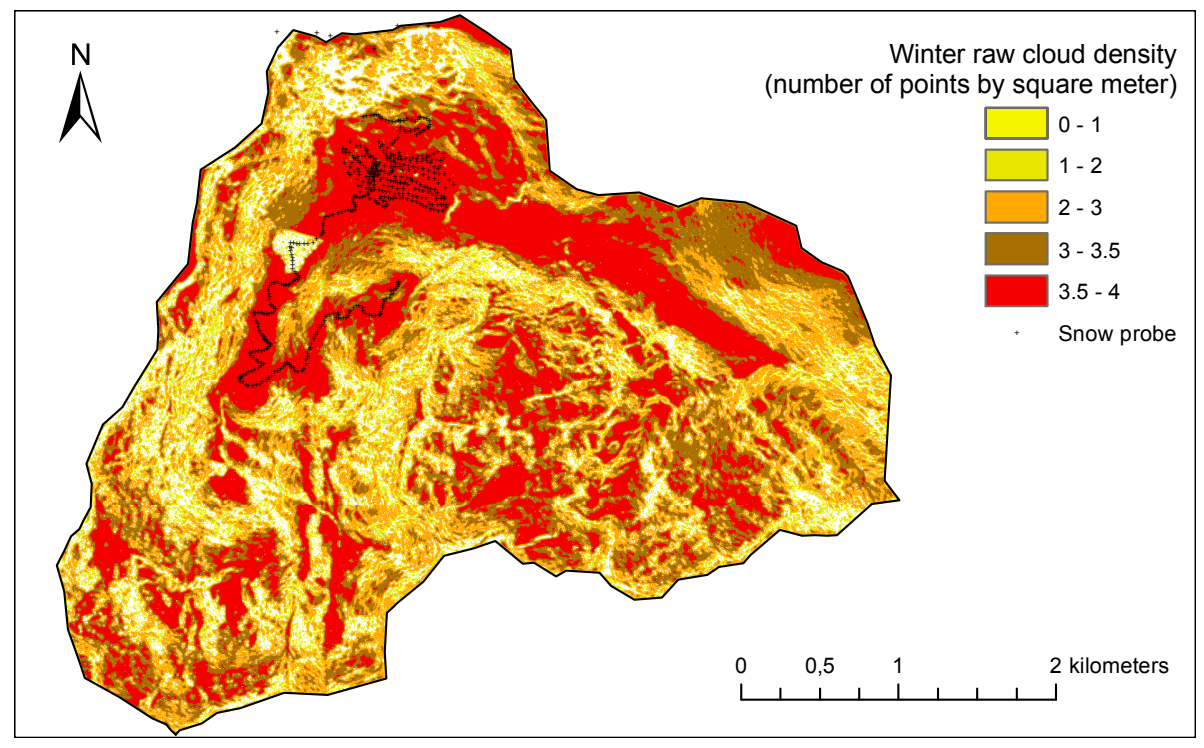

Figure 3: Density of the point cloud generated from the winter Pleiades triplet image (number of points per square meter). 


\section{Random error assessments}

The random error on the DGPS measurements were provided during the post-treatment step by the GPS Pathfinder office software (V. 5.4). Such estimations are based on the GDOP (Geometrical Dilution of Precision) associated to the positions and the distance to the correction base $(21 \mathrm{~km}$ in our study). The random error associated to the probe measurements are mainly due to penetration of the probe tip into the snow substrate, the reading between two probe spacing, and the verticality of the snow probe. According to the error propagation law, the random errors terms due to the DGPS and the snow-probe measurements were estimated as follows:

- random error term due to the DGPS measurements: $\sigma_{D G P S}=0.1 \mathrm{~m}$

- random error term due to the probe measurements: $\sigma_{\text {probe }}=0.15 \mathrm{~m}$

- random error term due to the DGPS and the snow-probe measurements:

$$
\sigma_{D G P S+\text { probe }}=\sqrt{\sigma_{D G P S}^{2}+\sigma_{\text {probe }}^{2}}=\sqrt{0.1^{2}+0.15^{2}}=0.18 \mathrm{~m}
$$

We estimated the random error in the 2m-DEMs and the 2m-dDEMS based on the SD of the residuals terms (equation (1), (3) and (4) from section 4.1) as follows:

- 2m-Pléiades Winter DEM:

$$
\sigma_{Z \text { winter }}=\sqrt{S D_{R_{Z_{w}}}^{2}-\sigma_{D G P S}^{2}}=\sqrt{0.32^{2}-0.1^{2}}=0.31 \mathrm{~m} .
$$

- 2m-Pléiades Snow-free DEM:

$$
\sigma_{Z \text { snow-free }}=\sqrt{S D_{R_{Z_{S}}}^{2}-\sigma_{D G P S}^{2}-\sigma_{\text {probe }}^{2}}=\sqrt{0.66^{2}-0.1^{2}-0.15^{2}}=0.63 \mathrm{~m} .
$$

- 2m-Pléiades dDEM:

$$
\sigma_{2 m-d D E M P l e i}=\sqrt{S D_{2 m-\Delta Z \text { Plei }}^{2}-\sigma_{\text {probe }}^{2}}=\sqrt{0.58^{2}-0.15^{2}}=0.56 \mathrm{~m}
$$

- 2m-UAS dDEM:

$$
\sigma_{2 m-d D E M U A S}=\sqrt{S D_{2 m-\Delta Z U A S}^{2}-\sigma_{\text {probe }}^{2}}=\sqrt{0.62^{2}-0.15^{2}}=0.60 \mathrm{~m}
$$

- 2m-Pléiades and UAS dDEMS differencing:

$$
\sigma_{2 m-\Delta(\Delta Z)}=\sqrt{\sigma_{2 m-\Delta Z \text { Plei }}^{2}+\sigma_{2 m-\Delta Z U A S}^{2}}=\sqrt{0.56^{2}+0.60^{2}}=0.82 \mathrm{~m}
$$

\section{Supplementary table}

In the case where the Pléiades dDEM pixel values were higher than the maximum snow-probe value, $H S_{\max }(50$ occurrences), the $\mathrm{dDEM}$ values are 40 to $50 \%$ of the cases also above this

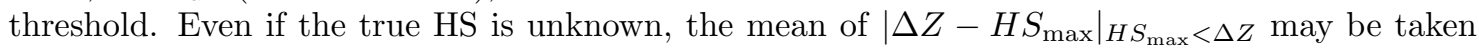
as an indication that the $\mathrm{dDEM}$ values are not inconsistent at this locations. The mean difference to the threshold value when the $\mathrm{dDEM}$ is below is $0.64 \mathrm{~m}$.

In the case where the UAV dDEM pixel values were higher than the maximum snow-probe value, $H S_{\max }$ (32 occurrences), $81 \%$ of the UAV dDEM values are also above this threshold. The mean of $\left|\Delta Z-H S_{\max }\right|_{H S_{\max }<\Delta Z}$ varies from 0.57 to $0.69 \mathrm{~m}$, according to the drone dDEM pixel resolution. 
Table 1: Percentage of dDEM pixel values which exceed the maximum snow-probe value $\left(H S_{\max }\right.$, $2.2 \mathrm{~m}$ and $3.2 \mathrm{~m}$ respectively, according to the type of the snow-probe). We also calculated the mean of the absolute difference between the dDEM value and $H S_{\max }$, in the cases where the pixel values were higher than $H S_{\max }$

\begin{tabular}{lcccc}
\hline $\begin{array}{l}\text { Data } \\
\text { source }\end{array}$ & $\begin{array}{c}\text { Pléiades dDEM } \\
\text { pixel size }\end{array}$ & $\begin{array}{c}\text { Number of } \\
\text { snow probe }\end{array}$ & $\begin{array}{c}\text { Percentage of } \\
\Delta Z>H S_{\max }\end{array}$ & $\begin{array}{c}\text { Mean of } \\
\text { Pléiades tri-stereo }\end{array}$ \\
\hline & $2 \mathrm{~m}$ & & $50 \%$ & $0.66 \mathrm{~m}$ \\
& $2 \mathrm{~m}$ & \multirow{2}{*}{50} & $40 \%$ & $0.68 \mathrm{~m}$ \\
& $4 \mathrm{~m}$ & & $40 \%$ & $0.59 \mathrm{~m}$ \\
\hline \multirow{3}{*}{$\mathrm{UAV}$} & $0.1 \mathrm{~m}$ & \multirow{2}{*}{32} & $81 \%$ & $0.69 \mathrm{~m}$ \\
& $1 \mathrm{~m}$ & & $81 \%$ & $0.57 \mathrm{~m}$ \\
& $2 \mathrm{~m}$ & & $81 \%$ & $0.66 \mathrm{~m}$ \\
\hline
\end{tabular}


Table 2: VHR optical (civil) satellites that have stereo capabilities comparable to Pléiades, i.e. that could be used for HS mapping based on the same method.(P) means panchromatic, (XS) means multispectral. The ${ }^{\circ} \mathrm{symbol}$, is the temporal resolution column, refers to the angle relative to the off nadir look (in degree). GSD means Ground Sample Distance.

\begin{tabular}{|c|c|c|c|c|c|c|}
\hline $\begin{array}{l}\text { Satellite platform } \\
\text { (launch date) }\end{array}$ & $\begin{array}{c}\text { Stereo- } \\
\text { capability }\end{array}$ & $\begin{array}{l}\text { Swath width } \\
\text { at nadir } \\
(\mathrm{km})\end{array}$ & $\begin{array}{l}\text { Temporal } \\
\text { resolution } \\
\quad(\text { day })\end{array}$ & $\begin{array}{l}\text { Spectral } \\
\text { resolution } \\
\quad(\mathrm{nm})\end{array}$ & $\begin{array}{l}\text { Radiometric } \\
\text { resolution } \\
\quad \text { (bits) }\end{array}$ & $\begin{array}{l}\text { Spatial } \\
\text { resolution } \\
\text { at nadir }\end{array}$ \\
\hline $\begin{array}{l}\text { Pléiades } 1 \mathrm{~A} \text { and } 1 \mathrm{~B} \\
(2011 \text { and } 2012)\end{array}$ & $\begin{array}{c}\text { Tri } \\
\text { and stereo }\end{array}$ & $20 \mathrm{~km}$ & $\begin{array}{l}1 \text { day with both } \\
\text { Pléiades satellites }\end{array}$ & $\begin{array}{l}480-830 \\
\mathrm{~nm}\end{array}$ & 12 bits & $\begin{array}{c}0.70 \mathrm{~m}(\mathrm{P}) \\
2.50 \mathrm{~m}(\mathrm{XS})\end{array}$ \\
\hline $\begin{array}{l}\text { GeoEye-1 } \\
(2008)\end{array}$ & stereo & $15.2 \mathrm{~km}$ & $\begin{array}{l}2.8 \text { days at } 28^{\circ} \\
8.3 \text { days at } 10^{\circ}\end{array}$ & $\begin{array}{l}450-800 \\
\mathrm{~nm}\end{array}$ & 11 bits & $\begin{array}{c}0.46 \mathrm{~m}(\mathrm{P}) \\
1.84 \mathrm{~m}(\mathrm{XS})\end{array}$ \\
\hline $\begin{array}{l}\text { WorldView-1 } \\
(2007)\end{array}$ & stereo & $17.7 \mathrm{~km}$ & $\begin{array}{c}1.7 \text { days at } 1 \mathrm{~m} \text { GSD } \\
5.4 \text { days at } 20^{\circ}(0.52 \mathrm{~m} \text { GSD })\end{array}$ & $\begin{array}{l}400-900 \\
\mathrm{~nm}\end{array}$ & 11 bits & $0.50 \mathrm{~m}(\mathrm{P})$ \\
\hline $\begin{array}{l}\text { WorldView-2 } \\
(2009)\end{array}$ & stereo & $16.4 \mathrm{~km}$ & $\begin{array}{c}1.1 \text { days at } 1 \mathrm{~m} \text { GSD } \\
3.7 \text { days at } 20^{\circ}(0.52 \mathrm{~m} \text { GSD })\end{array}$ & $\begin{array}{l}450-800 \\
\mathrm{~nm}\end{array}$ & 11 bits & $\begin{array}{c}0.46 \mathrm{~m}(\mathrm{P}) \\
1.85 \mathrm{~m}(\mathrm{XS})\end{array}$ \\
\hline $\begin{array}{l}\text { WorldView-3 } \\
(2014)\end{array}$ & stereo & $13.1 \mathrm{~km}$ & $\begin{array}{l}1 \text { day at } 1 \mathrm{~m} \text { GSD } \\
4.5 \text { days at } 20^{\circ} .\end{array}$ & $\begin{array}{l}450-800 \\
\mathrm{~nm}\end{array}$ & 11 bits & $\begin{array}{c}0.31 \mathrm{~m}(\mathrm{P}) \\
1.24 \mathrm{~m}(\mathrm{XS})\end{array}$ \\
\hline $\begin{array}{l}\text { SPOT } 6 \text { and } 7 \\
(2012 \text { and } 2014)\end{array}$ & $\begin{array}{c}\text { Tri } \\
\text { and stereo }\end{array}$ & $60 \mathrm{~km}$ & $\begin{array}{l}1 \text { day with both } \\
\text { SPOT satellites }\end{array}$ & $\begin{array}{c}450-745 \\
\mathrm{~nm}\end{array}$ & 12 bits & $\begin{array}{c}1.50 \mathrm{~m}(\mathrm{P}) \\
6.00 \mathrm{~m}(\mathrm{XS})\end{array}$ \\
\hline
\end{tabular}


Table 3: Overview of remote-sensing techniques which can be used to map snow depth. The spatial resolution, spatial extent, and given accuracies should be interpreted as "typical values" generally observed in the literature (e.g. (Dietz et al., 2012, Deems et al., 2013, Nolan et al., 2015, Bühler et al., 2015, Harder et al., 2016, Bühler et al., 2016)).

\begin{tabular}{|c|c|c|c|c|}
\hline $\begin{array}{l}\text { Remote-sensing } \\
\text { techniques }\end{array}$ & $\begin{array}{c}\text { Spatial resolution } \\
(\mathrm{m})\end{array}$ & $\begin{array}{l}\text { Spatial extent } \\
\left(\mathrm{km}^{2}\right)\end{array}$ & $\begin{array}{c}\text { Random error } \\
\text { in HS mapping }(\mathrm{m})\end{array}$ & $\begin{array}{l}\text { Snow-mapping context } \\
\text { \& suitable applications }\end{array}$ \\
\hline Airborne Lidar & $0.30-2 \mathrm{~m}$ & $5-100 \mathrm{~s} \mathrm{~km}^{2}$ & $0.10-0.30 \mathrm{~m}$ & $\begin{array}{c}\text { Thin and thick snow-pack }(>0.30 \mathrm{~m}) \\
\text { including over forested areas } \\
\text { Spatially distributed } S W E \\
\text { Avalanche danger mapping } \\
\text { Input for hydrological model }\end{array}$ \\
\hline
\end{tabular}

\begin{tabular}{|c|c|c|c|c|}
\hline " from manned airplane & $0.10-2 \mathrm{~m}$ & $5-100 \mathrm{~s} \mathrm{~km}{ }^{2}$ & $0.10-0.30 \mathrm{~m}$ & $\begin{array}{c}\text { Thin and thick snow-pack }(>0.30 \mathrm{~m}) \\
\text { Spatially distributed } S W E \\
\text { Avalanche danger mapping } \\
\text { Input for hydrological model }\end{array}$ \\
\hline " from UAV system & $0.05-2 \mathrm{~m}$ & $0.1-5 \mathrm{~km}^{2}$ & $0.08-0.20 \mathrm{~m}$ & $\begin{array}{c}\text { Thin and thick snow-pack }(>0.30 \mathrm{~m}) \\
\text { Sites well connected with transports } \\
\text { Ablation monitoring by multi- } \\
\text { temporal acquisitions } \\
\text { Very fine-scaled snow features monitoring } \\
\text { Spatially distributed SWE of very } \\
\text { small watershed }\end{array}$ \\
\hline
\end{tabular}

Satellite

" photogrammetry $\quad 1-2 \mathrm{~m} \quad 10-1500 \mathrm{~km}^{2} \quad 0.50-0.70 \mathrm{~m}$

Spatially distributed SWE at snow-peak Input for hydrological model

Snow-accumulation mapping over glaciers

" passive micro-wave $\quad 10-25 \mathrm{~km} \quad 1000 \mathrm{~s} \mathrm{~km}^{2}-$ global $\quad 0.05-0.50 \mathrm{~m}$

Thin prairie "dry" snow-pack $(<1 \mathrm{~m})$ or large plateau thin snow-pack Spatially distributed SWE of cold, thin snow in areas with simple topography even in cloudy conditions

" radar $10-30 \mathrm{~m} \quad 1000 \mathrm{~s} \mathrm{~km}^{2} \quad \begin{array}{r}\text { potentially } \\ \text { subdecimetric }\end{array}$

Prairie and alpine snow-pack Spatially distributed SWE even in cloudy conditions

(only in a research context up to now and with limited success due to inappropriate frequencies) 


\section{References}

Bühler, Y., Marty, M., Egli, L., Veitinger, J., Jonas, T., Thee, P., and Ginzler, C.: Snow depth mapping in high-alpine catchments using digital photogrammetry, The Cryosphere, 9, 229-243, doi:10.5194/tc-9-229-2015, 2015.

Bühler, Y., Adams, M. S., Bösch, R., and Stoffel, A.: Mapping snow depth in alpine terrain with unmanned aerial systems (UAS): potential and limitations, The Cryosphere Discussions, pp. 1-36, doi:10.5194/tc-2015-220, 2016.

Deems, J. S., Painter, T. H., and Finnegan, D.: Lidar measurement of snow depth: a review, Journal of Glaciology, 59, 467-479, doi:10.3189/2013JoG12J154, 2013.

Dietz, A. J., Kuenzer, C., Gessner, U., and Dech, S.: Remote sensing of snow - a review of available methods, International Journal of Remote Sensing, 33, 4094-4134, doi:10.1080/01431161.2011. 640964, 2012.

Harder, P., Schirmer, M., Pomeroy, J., and Helgason, W.: Accuracy of snow depth estimation in mountain and prairie environements by an unmanned vehicle, The Cryosphere Discussions, pp. 1-22, doi:10.5194/tc-2016-9, 2016.

Nolan, M., Larsen, C., and Sturm, M.: Mapping snow depth from manned aircraft on landscape scales at centimeter resolution using structure-from-motion photogrammetry, The Cryosphere, 9, 1445-1463, doi:10.5194/tc-9-1445-2015, 2015. 